Prepared in cooperation with the Millennium Challenge Corporation

\title{
Groundwater Resources of Ribeira Fajã Basin, Island of São Nicolau, Cape Verde, West Africa
}

\section{Overview of Cape Verde baseline groundwater study}

\section{Why was the study done?}

Groundwater resources in Cape Verde provide water for agriculture, industry, and human consumption. These resources are limited and susceptible to contamination. Additional groundwater resources are needed for continued agricultural development, particularly during times of drought, but increased use and (or) climatic change may have adverse effects on the quantity and quality of freshwater available. In volcanic island aquifers such as those of Cape Verde, a lens of fresh groundwater typically "floats" upon a layer of brackish water at the freshwater/saltwater boundary, and increased pumping may cause salt water intrusion or other contamination. A recent U.S. Geological Survey study (Heilweil and others, 2006, 2009) assessed baseline groundwater conditions in watersheds on three islands of Cape Verde to provide the scientific basis for sustainably developing water resources and minimizing future groundwater depletion and contamination.

\section{Setting and approach}

Cape Verde is an archipelago of nine inhabited islands located about 750 kilometers off the west coast of Africa (fig. 1). Three watersheds were studied for the baseline groundwater study: Ribeira Fajã Basin on São Nicolau (this fact sheet), Mosteiros Basin on Fogo (Heilweil and others, 2010a), and Ribeira Paúl Basin on Santo Antão (Heilweil and others, 2010b). Rainfall in Cape Verde varies greatly from year to year and with elevation. Average annual rainfall ranges from less than 50 millimeters along the populated coastal areas up to 1,000 millimeters in the highlands. Most of the population resides in rural areas and derives its livelihood from rain-fed $24^{\circ}$

$23^{\circ}$

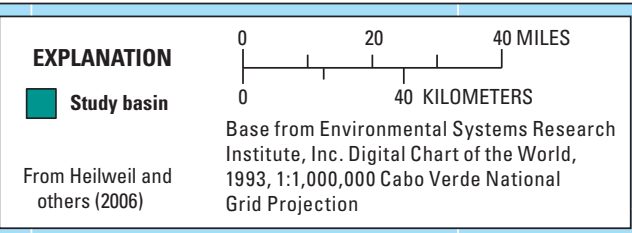

Santa Luzia Ribeira Fajã
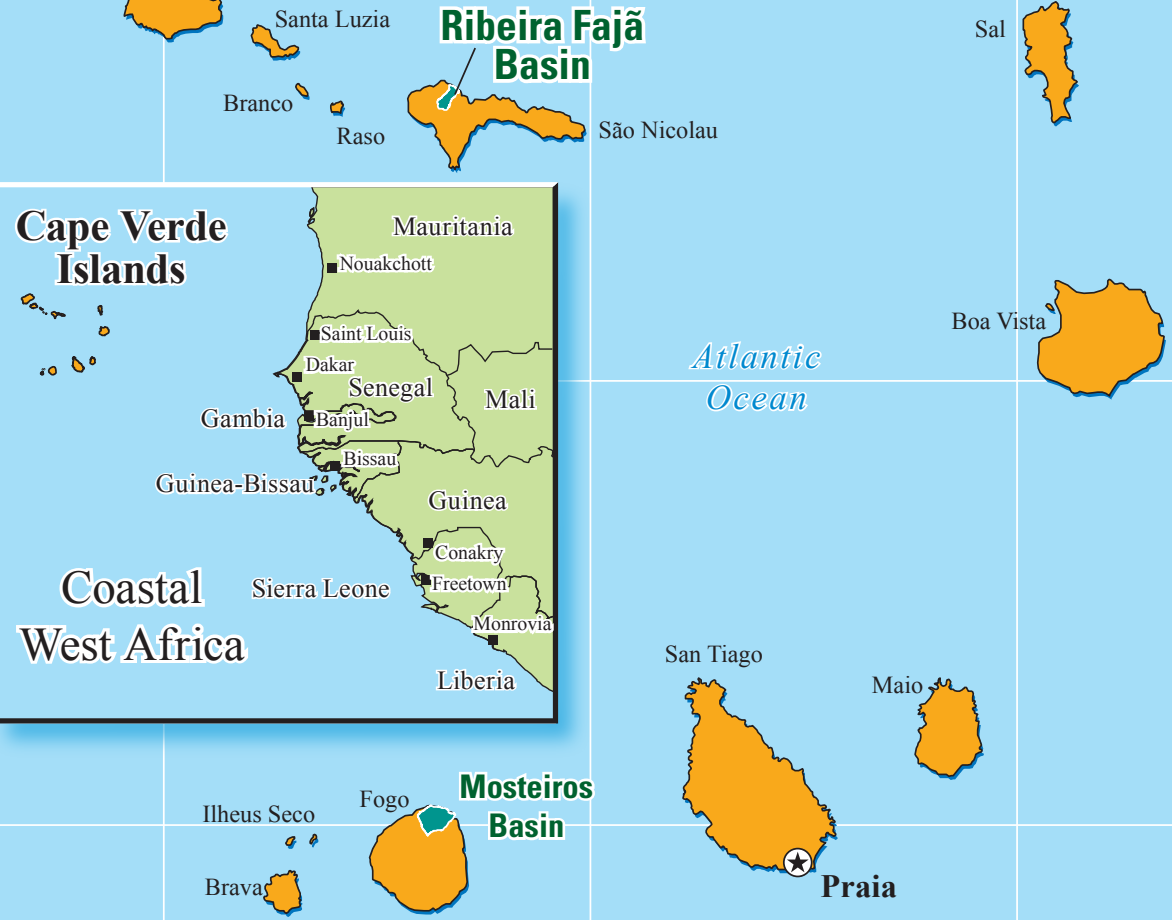

Ocean
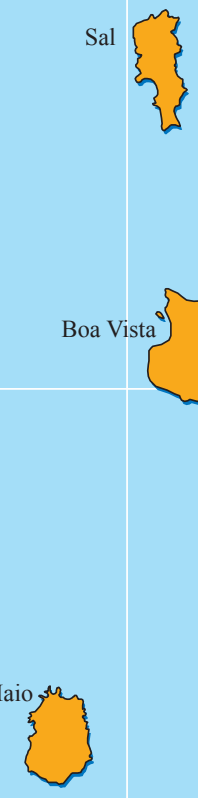

Praia

Figure 1. Location of study basins within Cape Verde, West Africa. 


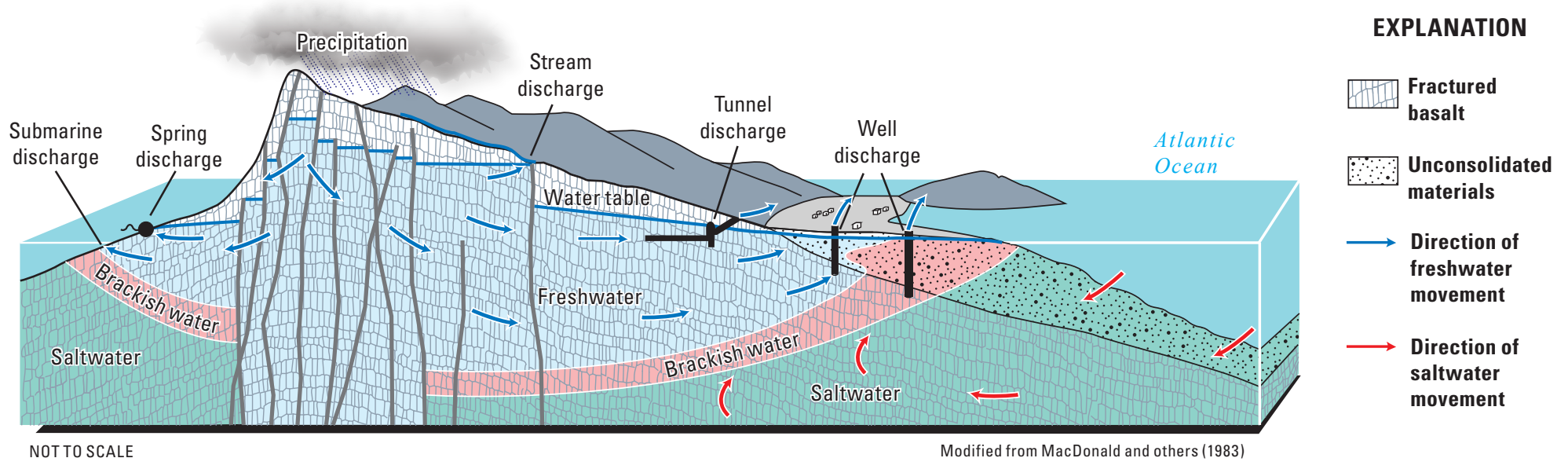

Figure 2. Generalized conceptual model of volcanic island hydrology.

\section{Ribeira Fajã Basin, São Nicolau}

\section{Results - What was learned?}

Ribeira Fajã (16 square kilometers)is the lowest and driest of the three study basins, having an average altitude of 480 meters and an estimated average annual rainfall of about 300 millimeters. Annual rainfall at the Cachaço precipitation station (fig. 3) varies from as little as 100 to almost 700 millimeters. Ribeira Fajã has no measurable natural groundwater discharge to springs or streams. Historically, there were springs in the lower part of the basin, but these dried up as a consequence of the completion of the Galleria Fajã tunnel in 1985. Groundwater drainage associated with this tunnel also caused water levels to decline 20 meters or more in nearby wells, two of which subse-

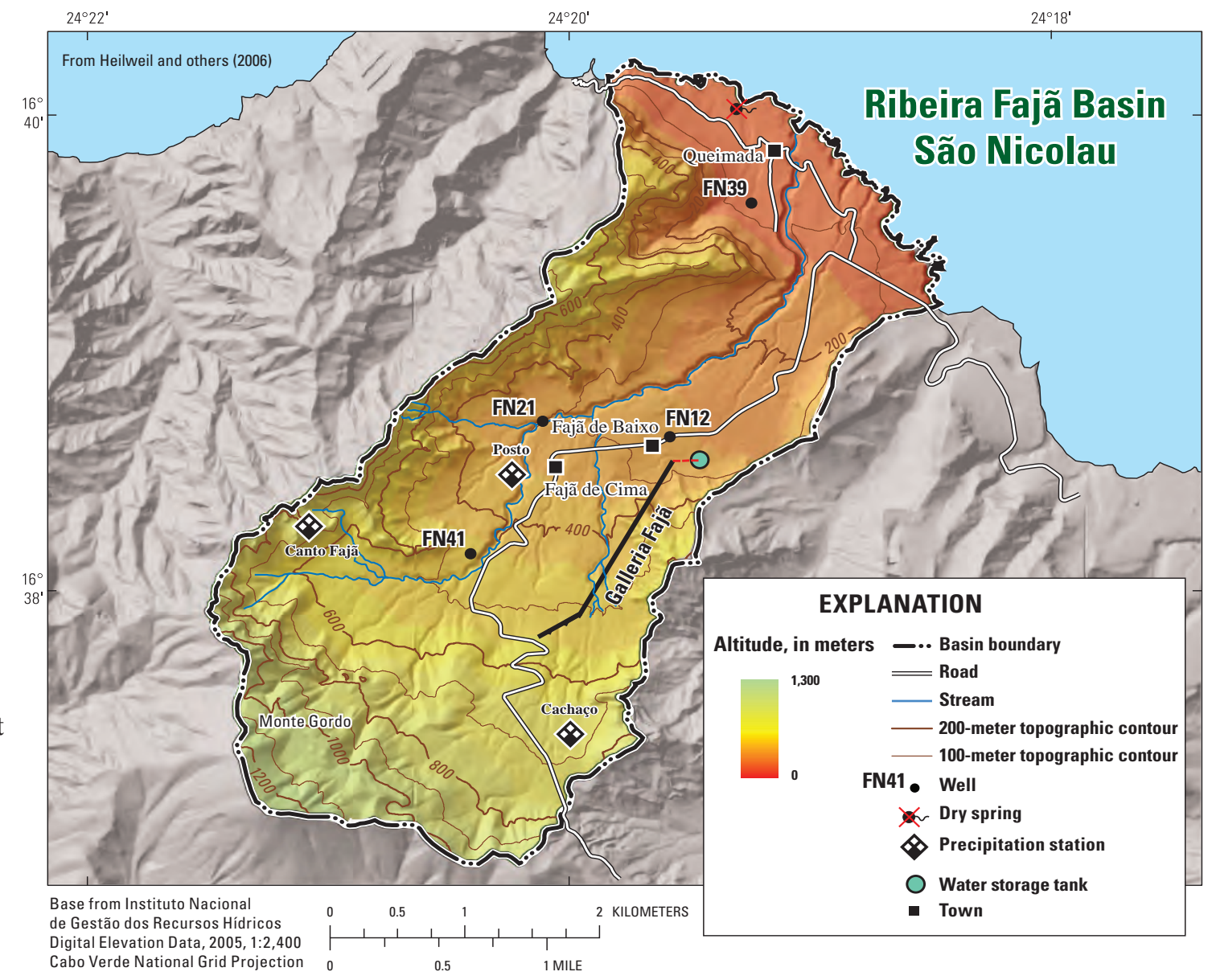

Figure 3. Hydrologic map of Ribera Fajã Basin, Island of São Nicolau. quently dried up. Discharge from the completed tunnel is now the only source of groundwater in the basin, but it has declined from an initial daily flow of 1,400 cubic meters to about 400 cubic meters in recent years. This decline was caused by aquifer de-watering associated with the tunnel rather than changes in rainfall (fig. 4). Based on this discharge amount, only about 3 percent of rainfall in the basin recharges the groundwater system, but this percentage may be higher if submarine discharge of groundwater is occurring off the coast of Ribeira Fajã.

Environmental tracers ${ }^{1}$ sampled in one well and three locations in the Galleria Fajã tunnel indicate that the groundwater in Ribeira Fajã Basin is older than 50 years. This is consistent with the lower rainfall and groundwater discharge than in the other two study basins, which have younger groundwater. Because of less precipitation and lower recharge, along with deeper groundwater levels, the groundwater system in Ribeira Fajã may not be as susceptible to contamination from agriculture and (or) septic systems as in the other basin. The quality of groundwater within the basin is generally very good. Less recharge in this basin than in the other two study basins, however, indicates that the lower part of the basin may be susceptible to saltwater intrusion due to well pumping.

${ }^{1}$ Environmental tracers used to determine age were tritium $\left({ }^{3} \mathrm{H}\right)$ and tritiogenic helium ( $\left.{ }^{3} \mathrm{He}_{\text {trit }}\right)$. G roundwater dating using the tritium/helium method was partially hampered by high concentrations of helium associated with volcanism or gases derived from the mantle. 

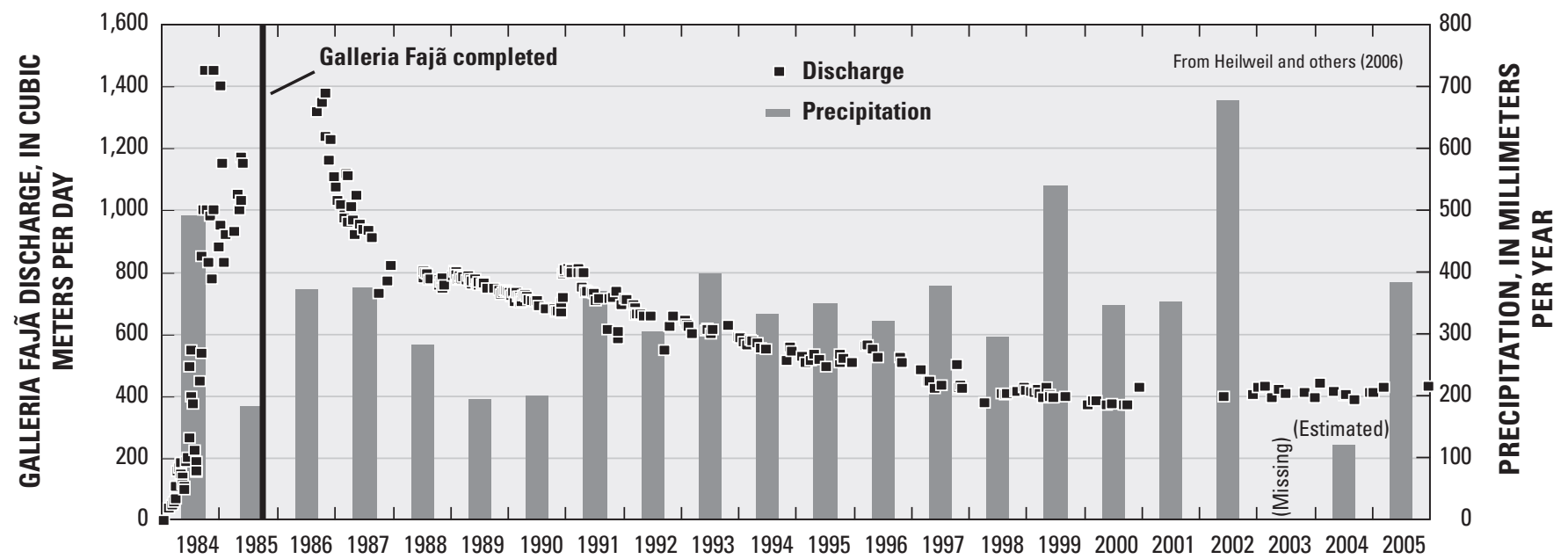

Figure 4. Graph showing discharge from the Galleria Fajã tunnel and rainfall in Ribeira Fajã Basin.

\section{Challenges for future water-resources development and management in Ribeira Fajã Basin}

- Groundwater resources in Ribeira Fajã Basin are limited in comparison to other watersheds in Cape Verde that have higher precipitation and infiltration.

- The completion of the Galleria Fajã tunnel in 1985 provided an additional source of water in the basin, but caused groundwater levels to decline rapidly and nearby wells and springs to dry up.

- Recharge enhancement (artificial recharge) in the basin is a possible mechanism for replenishing groundwater storage, but must take into account permeability of surficial soils and underlying bedrock.

- The quality of groundwater within the basin is generally very good and no wells are currently being pumped. To minimize

By Victor M. Heilweil, Stephen B. Gingerich,

L. Niel Plummer, and Ingrid M. Verstraeten the risk of saltwater intrusion, however, future groundwater development near the coast should be limited.

- Because of water-quality and water-quantity concerns in Ribeira Fajã Basin, careful stewardship and management practices will be essential for protecting water resources for future generations.

\section{By frequently monitoring discharge from the Galleria Fajã tunnel, rainfall, water-level changes, groundwater chemistry (salinity and nitrates), and possible future well pumping, scientifically based metrics can be established to ensure sustainable future groundwater and agricul- tural development in Ribeira Fajã Basin.}

\section{Acknowledgements}

The USGS thanks the Millennium Challenge Account - Cape Verde, the Instituto Nacional de Gestão dos Recursos Hídricos, and local water management agencies in Mosteiros, Ribeira Paúl and Ribeira Fajã, for providing historical information and assistance with hydrologic data collection and interpretation.

\section{Additional resources}

Haagsma, B., 1995, Traditional water management and state intervention: The case of Santo Antão, Cape Verde: Mountain Research and Development, v. 15, no. 1, p. 39-56.

Heilweil, V.M., Earle, J.D., Cederberg, J.R., Messer, M.M., Jorgensen, B.E., Verstraeten, I.M., Moura, M.A., Querido, A., Spencer, F., and Osorio, T., 2006, Evaluation of baseline ground-water conditions in the Mosteiros, Ribeira Paúl, and Ribeira Fajã Basins, Republic of Cape Verde, West Africa, 2005-06: U.S. Geological Survey Scientific Investigations Report 2006-5207, 42 p.

Heilweil, V.M., Gingerich, S.B., Plummer, L.N., Verstraeten, I.M., 2010a, Groundwater resources of Mosteiros Basin, Island of Fogo, Cape Verde, West Africa: U.S. Geological Survey Fact Sheet 2010-3069, 6 p.

Heilweil, V.M., Gingerich, S.B., Plummer, L.N., Verstraeten, I.M., 2010b, Groundwater resources of Ribeira Paúl Basin, Island of Santo Antão, Cape Verde, West Africa: U.S. Geological Survey Fact Sheet 2010-3070, $6 \mathrm{p}$

Heilweil, V.M., Solomon, D.K., Gingerich, S.B., and Verstraeten, I.M., 2009, Oxygen, hydrogen, and helium isotopes for investigating groundwater systems of the Cape Verde Islands, West Africa: Hydrogeology Journal, v. 17 , no. $5,1157-1174$.

Langworthy, M. and Finan, T.J., 1997, Waiting for rain: Agriculture and ecological imbalance in Cape Verde: Boulder, Colorado, Lynne Rienner Publishers, ISBN 1-55587-709-5, 212 p.

MacDonald, G.A., Abbott, A.T., and Peterson, F.L., 1993, Volcanoes in the sea: The geology of Hawaii (2nd ed.): Honolulu, Hawaii, University of Hawaii Press, 517 p.
For more information, contact:

International Water Resources Branch

U.S. Geological Survey

12201 Sunrise Valley Drive

Reston, Virginia 20192

703-648-5230

This publication is available online at: http://pubs.usgs.gov/fs/2010/3071 